\title{
16. SOME TRACE ELEMENTS IN THE CARBONATE SAMPLES RECOVERED FROM HOLES 390, 390A, 391C, AND 392A OF DSDP LEG 44
}

\author{
Maurice Renard, ${ }^{1}$ Réne Létolle, ${ }^{1}$ Maurice Bourbon, ${ }^{2}$ \\ and Gilbert Richebois ${ }^{1}$
}

We determined concentrations of trace elements in the carbonate fraction by atomic absorption analysis following the procedure described by Renard and Blanc $(1971,1972)$. The age of the samples studied range from Barremian to middle Eocene (Holes 390, 390A), Tithonian to Aptian (Hole 391C), and late Campanian to Barremian (Hole 392A). Mineralogically, they all contain low magnesian calcite. The results of the analysis are given in Tables 1 to 4 .

\section{HOLE 391C}

\section{Relationship With Insoluble Residues}

In some samples, we obtained sufficient insoluble residues, following treatment with acetic acid, to relate certain element concentrations to percentage of insoluble residue (Figure 1). We noted a distinct, positive correlation between concentrations of potassium, sodium, and magnesium and the percentage of insoluble residue. (Some of these elements may have been flushed into the insoluble fraction in spite of the precautions taken.) We found a positive, but less pronounced, relationship between zinc and strontium concentrations and insoluble residue, whereas we detected no correlation between manganese concentrations and insoluble residue. Because of this relationship we consider the results obtained for potassium, sodium, and magnesium, and those obtained for strontium, and zinc, when the samples contain more than 10 per cent insoluble, to be unreliable.

\section{Strontium}

The concentration curve of strontium contents is very characteristic for samples containing more than 90 per cent carbonates (Figure 2). The amount of strontium decreases continuously from the Aptian to the Tithonian sediments; a rapid decrease occurs in the lower Valanginian-upper Barremian sediments. We attribute this to increased diagenesis with greater depth which reflects the degree of diagenesis as a function of age. This is consistent with earlier claims of Sheerman and Shirmohammadi (1969), Kinsman (1969), and Renard (1972) that strontium is a reliable measure of carbonate diagenesis. The similarity of the strontium concentrations and the sediment accumulation curves illustrates that the highest rate of sedimentation $\left(2.8 \mathrm{~cm} / 10^{3}\right.$ years $)$ corresponds to the greatest loss of strontium. A rough correlation between the gradient of the strontium concentration curve and the sedimentation rate is given in Figure 3.

'U.E.R. des Sciences de la Terre, Université Pierre and Marie Curie, Paris, France.

${ }^{2}$ Ecole Nationale des Mines de Paris, France.

\section{Manganese}

We distinguished two zones in Hole 391C on the basis of the manganese concentrations (Figure 4). One zone, in lower Tithonian and lower Berriasian sediments, has high manganese concentrations. The second zone, between the upper Berriasian to the lower Aptian sediments, has low manganese concentrations. The behavior of manganese during sedimentation is complex inasmuch as it can be coprecipitated with calcium carbonate or as dioxide. In a reducing medium, co-precipitation predominates and produces low manganese carbonates; in an oxidizing medium, dioxide precipitation predominates producing "carbonates rich in manganese" (Michard, 1969). If the oxidationreduction mechanisms alone were responsible for the variation in manganese concentrations, we would expect maximum values in the Aptian to upper Valanginian sediments, which, because they were deposited at slower rates and during a time of little subsidence, were exposed a relatively long time to an oxidizing environment. In Hole 391C, however, the greatest amounts of manganese are found in the zone characterized by a high sedimentation rate (Berriasian-Tithonian). This suggests that variations in the manganese content may reflect variations in supply of manganese to the sediment. The manganese may have had a volcanic origin, especially as volcanic glass has been found in several manganese-rich samples (391C-52-2, for example). Michard (1975) has shown that seawater in contact with basalt is strongly enriched in manganese; moreover iron- and manganese-rich hydrothermal sources were detected along certain transcurrent faults during the FAMOUS expedition of 1974 (in Michard, 1975). If we accept that the manganese in the Berriasian-Tithonian sediments has a volcanic source, then its reduction in the overlying sediments suggests a decrease of volcanic activity during late Berriasian to the end of Aptian time.

The curves giving the partition of iron and manganese concentrations show an inverse relationship (Figure 5). Manganese concentrations are always highest where iron concentrations are lowest. If the early Tithonian manganese is of volcanic origin, the iron must have a different origin, which is inconsistent with results of the FAMOUS expedition and other data, or it was precipitated as less soluble iron oxide and hydroxide near the volcanic ridge.

The Hauterivian to Barremian zone has the highest iron and the lowest manganese concentrations. Note that ironrich samples always have a low carbonate content. The iron could then be of continental detrital origin and may reflect an early stage of the transition from a carbonate to siliciclastic depositional environment which culminated, near the end of the Upper Cretaceous, with the deposition of black 

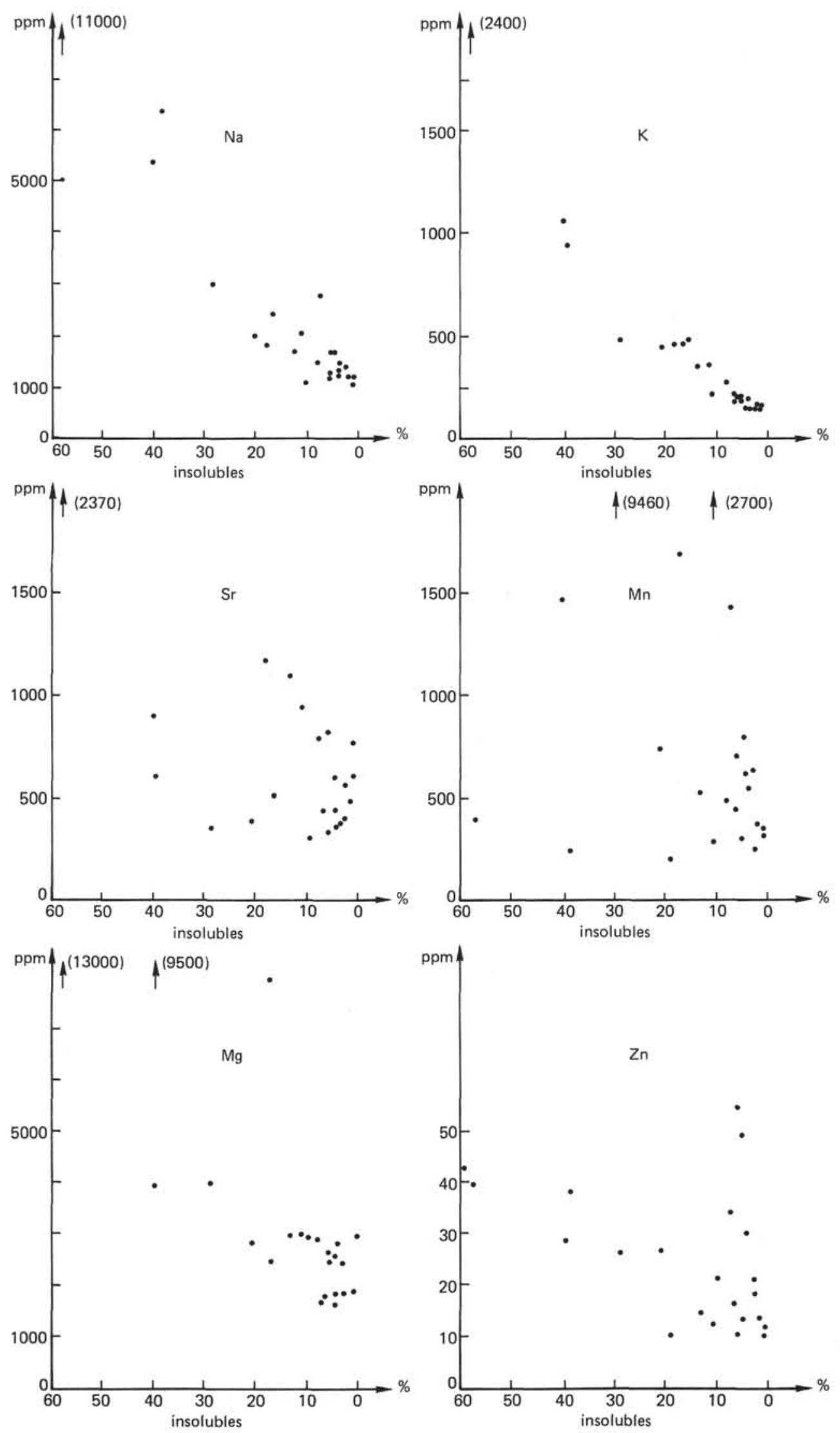

Figure 1. Relationship between certain element concentrations and percentages of insoluble residues in Hole $391 C$. 


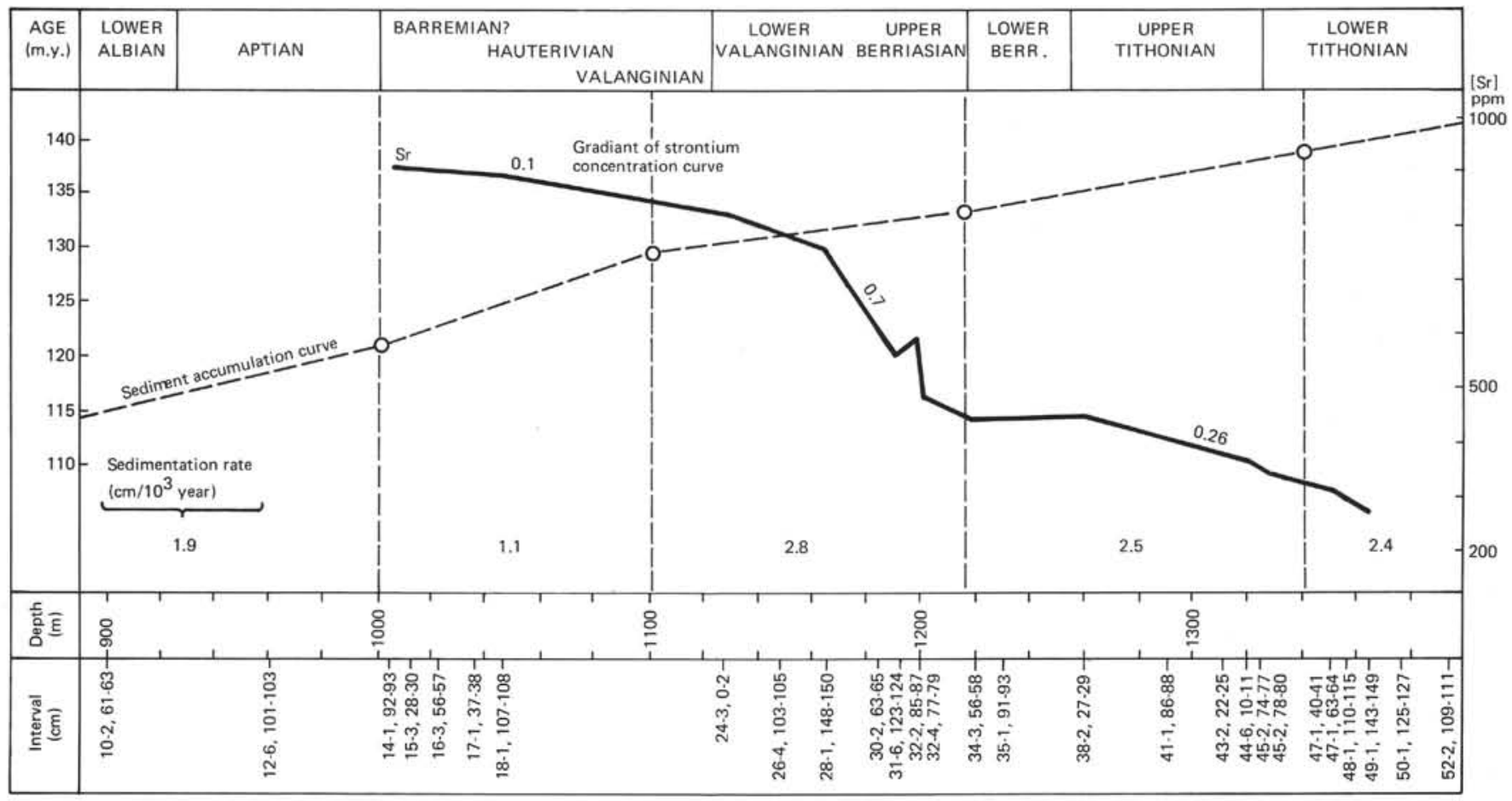

Figure 2. Distribution of strontium contents in Hole $391 \mathrm{C}$ compared with sediment accumulation.

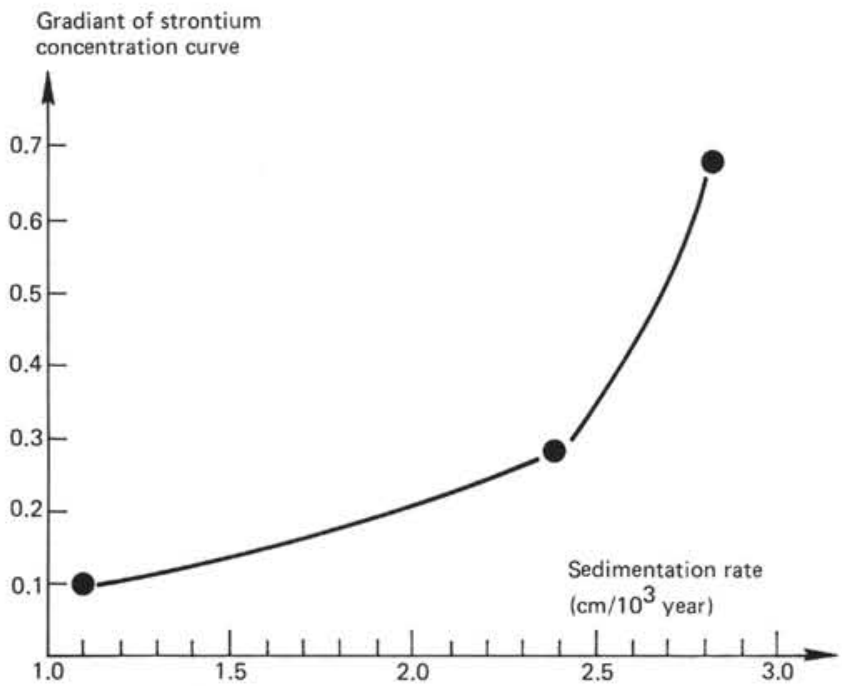

Figure 3. Correlation between the sedimentation rate and the gradient of the strontium-concentration curve.

shales. The Fe-Mn diagram (Figure 6) shows the existence of two zones corresponding to different types of sediment supply: those of volcanic origin, characterized by a high $\mathrm{Mn} / \mathrm{Fe}$ ratio and comprising in particular Tithonian samples; and those of continental origin, characterized by a low $\mathrm{Mn} / \mathrm{Fe}$ ratio and comprising Valanginian to Barremian samples.

Volcanic materials may have been supplied again during the Albian, but we cannot corroborate this on the basis of available samples. Data for Hole 391C are presented on Table 1.

\section{HOLES 390 AND 390A}

Preliminary data for strontium, manganese, and iron from the carbonate fraction are presented in Tables 2 and 3 . We did not detect any relationship between the concentrations of these elements and the percentage of insoluble residues.

\section{Strontium}

The strontium concentration curve for the Cretaceous part of this interval is similar to that of Hole 391C: strontium continuously decreases from Maestrichtian to Barremian sediments as a function of greater diagenesis with increased age, and a possible contribution from vadose solution (Létolle et al., this volume). The top of zone of decreasing strontium, however, is in Maestrichtian sediments (110 m depth) and hence at a shallower level than in Hole 391C (Valanginian, $1100 \mathrm{~m}$ depth).

Near the Cretaceous/Tertiary boundary, the strontiumconcentration curve shows a very important discontinuity (Figure 7). A rapid decrease registered in the upper Maestrichtian continues in Danian sediments. In overlying sediments the strontium curve, though generally regular, shows several oscillations from 500 to $750 \mathrm{ppm}$. For example, the upper boundary of the lower Eocene is characterized by another rapid decrease of the strontium concentration.

Presently we can offer no explanation for these variations although several possibilities exist.

1) Variation of temperature $\left(\mathrm{Ksr}\right.$ calcite $=0.14$ at $25^{\circ} \mathrm{C}=$ 0.08 at $\left.100^{\circ} \mathrm{C}\right)$,

2) Variation of the strontium metabolism of nannofossils,

3) Variation of the ratio $\mathrm{Sr}^{2}+/ \mathrm{Ca}^{2}+$ of seawater,

4) Variation of the clastic carbonate supply. 
TABLE 1

Results of Trace Element Analyses, Hole 391C

\begin{tabular}{|c|c|c|c|c|c|c|c|c|c|c|}
\hline $\begin{array}{c}\text { Sample } \\
\text { (Interval in cm) }\end{array}$ & $\begin{array}{c}\mathrm{Sr} \\
(\mathrm{ppm})\end{array}$ & $\underset{(\mathrm{ppm})}{\mathrm{Mg}}$ & $\underset{(\mathrm{ppm})}{\mathrm{Na}}$ & $\underset{(\mathrm{ppm})}{\mathrm{K}}$ & $\underset{(\mathrm{ppm})}{\mathrm{Mn}}$ & $\underset{(\mathrm{ppm})}{\mathrm{Zn}}$ & $\begin{array}{c}\mathrm{Fe} \\
(\mathrm{ppm})\end{array}$ & $\begin{array}{c}\mathrm{CaCo}_{3} \\
(\%)\end{array}$ & Chronostrati. & Lithology \\
\hline $10-2,61-63$ & 369 & 3926 & 3049 & 462 & 9469 & 26 & 1074 & 71.45 & Lower Albian & Limestone \\
\hline $12-6,101-103$ & 899 & 9534 & 6356 & 931 & 241 & 37 & 2290 & 61.46 & Aptian & Nannofossil limestone \\
\hline $14-1,92-93$ & 911 & 2956 & 2034 & 349 & 290 & 11 & 1774 & 89.19 & \multirow{9}{*}{$\begin{array}{l}\text { Barremian? } \\
\text { Hauterivian } \\
\text { Lower } \\
\text { Valanginian }\end{array}$} & Limestone \\
\hline $15-3,28-30$ & 1163 & 8131 & 1784 & 440 & 192 & 10 & 2965 & 82.58 & & Clayey limestone \\
\hline $16-3,56-57$ & 2370 & 13156 & 11100 & 2448 & 383 & 39 & 4090 & 42.80 & & $\begin{array}{l}\text { Limestone with } \\
\text { shale }\end{array}$ \\
\hline $17-1,97-98$ & 1104 & 3070 & 1747 & 348 & 513 & 13 & 2597 & 87.49 & & Sandy limestone \\
\hline $18-1,107-108$ & 878 & 6388 & 5135 & 1376 & 614 & 43 & 5252 & 40.09 & & Sandy limestone \\
\hline $24-3,0-2$ & 820 & 2460 & 1288 & 193 & 433 & 10 & 890 & 94.38 & & $\begin{array}{l}\text { Laminated and bioturbated } \\
\text { limestone }\end{array}$ \\
\hline $26-4,103-105$ & 791 & 2911 & 1560 & 257 & 483 & 33 & 1966 & 92.63 & & $\begin{array}{l}\text { Laminated and bioturbated } \\
\text { limestone }\end{array}$ \\
\hline $28-1,148-150$ & 755 & 2975 & 1091 & 160 & 314 & 10 & 2215 & 99.47 & & $\begin{array}{l}\text { Laminated and bioturbated } \\
\text { limestone }\end{array}$ \\
\hline $30-2,63-65$ & 610 & 1886 & 1220 & 141 & 355 & 11 & 2074 & 99.38 & & $\begin{array}{l}\text { Laminated and bioturbated } \\
\text { limestone }\end{array}$ \\
\hline $31-6,123-124$ & 564 & 1808 & 1458 & 186 & 241 & 17 & 1918 & 97.75 & \multirow[t]{3}{*}{$\begin{array}{l}\text { Upper } \\
\text { Berriasian }\end{array}$} & $\begin{array}{l}\text { Laminated and bioturbated } \\
\text { limestone }\end{array}$ \\
\hline $32-2,85-87$ & 598 & 1826 & 1770 & 188 & 299 & 13 & 2080 & 95.54 & & $\begin{array}{l}\text { Laminated and bioturbated } \\
\text { limestone }\end{array}$ \\
\hline $32-4,77-79$ & 489 & 1724 & 1245 & 163 & 361 & 12 & 2168 & 98.84 & & $\begin{array}{l}\text { Laminated and bioturbated } \\
\text { limestone }\end{array}$ \\
\hline $34-3,56-58$ & 440 & 1760 & 2827 & 220 & 1430 & 16 & 2282 & 93.40 & \multirow[t]{3}{*}{$\begin{array}{l}\text { Lower } \\
\text { Berriasian }\end{array}$} & Clayey limestone \\
\hline $35-1,91-93$ & 514 & 1970 & 2451 & 449 & 1685 & 13 & 2254 & 83.85 & & Clayey limestone \\
\hline $38-2,27-29$ & 449 & 1588 & 1731 & 204 & 789 & 13 & 1534 & 95.47 & & Limestone \\
\hline $41-1,86-88$ & 405 & 2462 & 1532 & 167 & 678 & 20 & 1456 & 97.59 & \multirow{6}{*}{$\begin{array}{l}\text { Upper } \\
\text { Tithonian }\end{array}$} & with clayey \\
\hline $43-2,22-25$ & 373 & 2559 & 1356 & 146 & 612 & 30 & 1502 & 96.58 & & stringers \\
\hline $44-6,10-12$ & 364 & 2811 & 1323 & 142 & 535 & 49 & 1257 & 96.32 & & Limestone \\
\hline $45-2,74-77$ & 343 & 2659 & 1307 & 173 & 687 & 54 & 1196 & 94.16 & & Interbedded "green and red" \\
\hline $45-2,78-80$ & 385 & 2862 & 2004 & 424 & 738 & 26 & 991 & 79.44 & & limestone \\
\hline $47-1,40-41$ & 611 & 3931 & 5460 & 1048 & 1463 & 28 & 437 & 60.63 & & Clayey limestone \\
\hline $47-1,63-67$ & 314 & 2975 & 1168 & 207 & 2700 & 21 & 1080 & 90.16 & \multirow{5}{*}{$\begin{array}{l}\text { Lower } \\
\text { Tithonian }\end{array}$} & Limestone \\
\hline $48-1,110-113$ & 906 & 5355 & 519 & 1005 & 2010 & 37 & 746 & 62.83 & & $\begin{array}{l}\text { Limestone with clay } \\
\text { stringers }\end{array}$ \\
\hline $49-1,143-149$ & 299 & 2825 & 124 & 148 & 3531 & 33 & 904 & 97.34 & & Limestone \\
\hline $50-1,125-127$ & 1239 & 5994 & 10656 & 1572 & 2131 & 46 & 333 & 52.03 & & Calcareous claystone \\
\hline $52-2,109-111$ & 3862 & 7347 & 15084 & 1742 & 9103 & 64 & 733 & 40.93 & & Claystone (volc. glass) \\
\hline
\end{tabular}

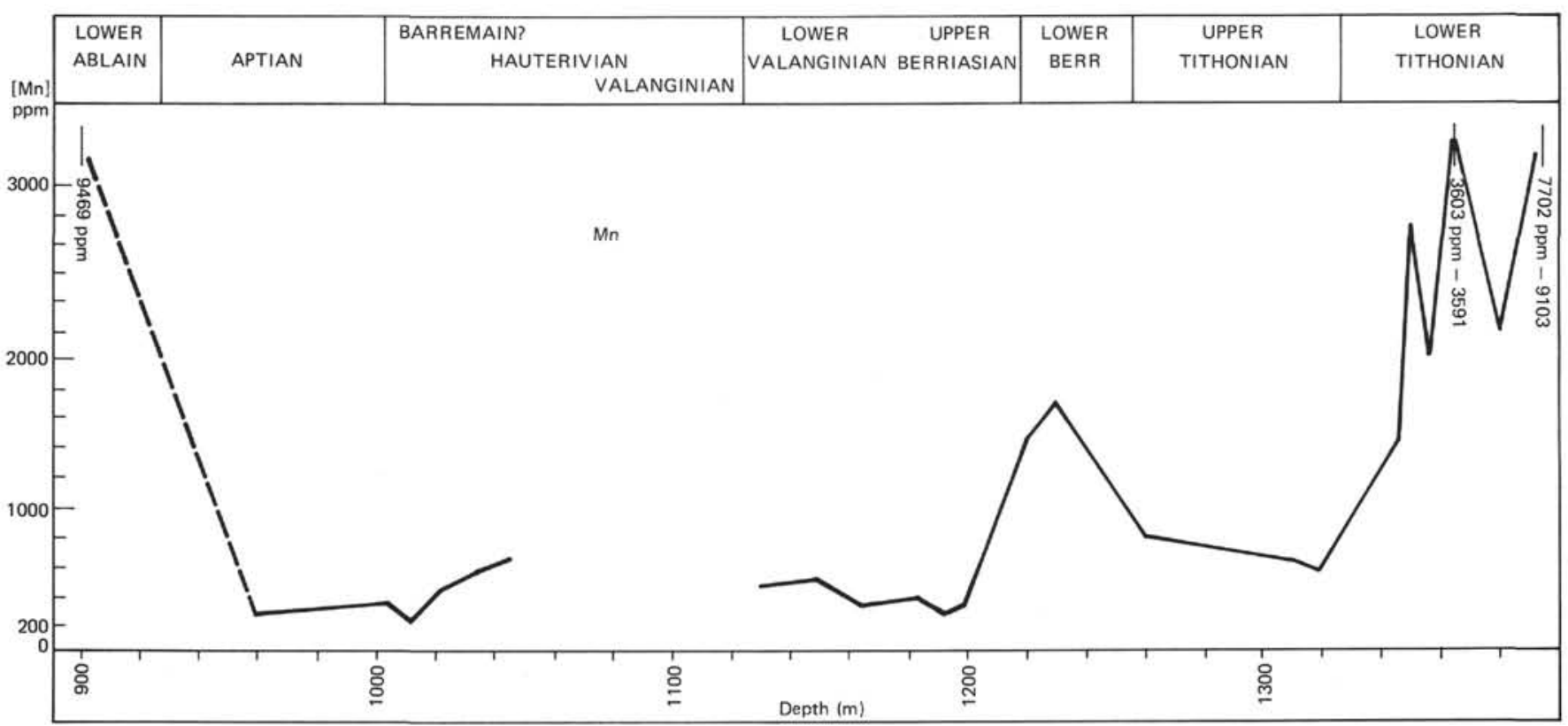

Figure 4. Distribution of manganese contents in Hole 391C. 
TABLE 2

Results of Trace Element Analyses, Hole 390

\begin{tabular}{|c|c|c|c|c|c|c|}
\hline $\begin{array}{c}\text { Sample } \\
\text { (Interval in } \mathrm{cm} \text { ) }\end{array}$ & $\begin{array}{c}\mathrm{Sr} \\
(\mathrm{ppm})\end{array}$ & $\begin{array}{c}\text { Mn } \\
(\mathrm{ppm})\end{array}$ & $\begin{array}{c}\mathrm{Fe} \\
(\mathrm{ppm})\end{array}$ & $\begin{array}{c}\mathrm{CaCO}_{3} \\
(\%)\end{array}$ & Chronostrat. & Lithology \\
\hline $\begin{array}{l}1-1,135-136 \\
1-3,86-87 \\
1-6,85-86\end{array}$ & $\begin{array}{l}521 \\
570 \\
620\end{array}$ & $\begin{array}{l}194 \\
204 \\
237\end{array}$ & $\begin{array}{l}25 \\
21 \\
27\end{array}$ & $\begin{array}{l}96.49 \\
93 \\
96.25\end{array}$ & $\begin{array}{l}\text { Middle } \\
\text { Eocene }\end{array}$ & $\begin{array}{l}\text { Nannofossil ooze } \\
\text { Nannofossil ooze } \\
\text { Nannofossil ooze }\end{array}$ \\
\hline $\begin{array}{l}3-1,112-114 \\
3-3,129-131 \\
3-3,147-149\end{array}$ & $\begin{array}{l}672 \\
548 \\
498\end{array}$ & $\begin{array}{r}103 \\
72 \\
239\end{array}$ & $\begin{array}{l}244 \\
396 \\
355\end{array}$ & $\begin{array}{l}49.29 \\
34.95 \\
38.07\end{array}$ & Campanian & $\begin{array}{l}\text { Nannofossil clay } \\
\text { Nannofossil clay } \\
\text { Nannofossil clay }\end{array}$ \\
\hline $\begin{array}{l}5-1,133-134 \\
5-2,138-140\end{array}$ & $\begin{array}{l}236 \\
293\end{array}$ & $\begin{array}{l}186 \\
167\end{array}$ & $\begin{array}{r}62 \\
431\end{array}$ & $\begin{array}{l}59.24 \\
72.54\end{array}$ & $\begin{array}{l}\text { Lower } \\
\text { Albian- } \\
\text { Barremian }\end{array}$ & $\begin{array}{l}\text { Nannofossil chalk } \\
\text { Nannofossil chalk (with } \\
\text { mudstone) }\end{array}$ \\
\hline $6-1,126-128$ & 152 & 268 & 177 & 99.79 & & $\begin{array}{l}\text { Calcareous ooze homogenized } \\
\text { by drilling }\end{array}$ \\
\hline $8-2,51-53$ & 234 & 176 & 118 & 95.52 & & Calcareous sand and gravel \\
\hline $8-4,131-133$ & 164 & 17 & 48 & 91.01 & Barremian? & $\begin{array}{l}\text { Chalk clasts and calcareous } \\
\text { mudstone }\end{array}$ \\
\hline $8-6,143-144$ & 145 & 16 & 37 & 91.51 & & Calcareous mud \\
\hline $9-1,78-80$ & 119 & 12 & 60 & 98.42 & & $\begin{array}{l}\text { Calcareous pseudogravel } \\
\text { and mudstone }\end{array}$ \\
\hline
\end{tabular}

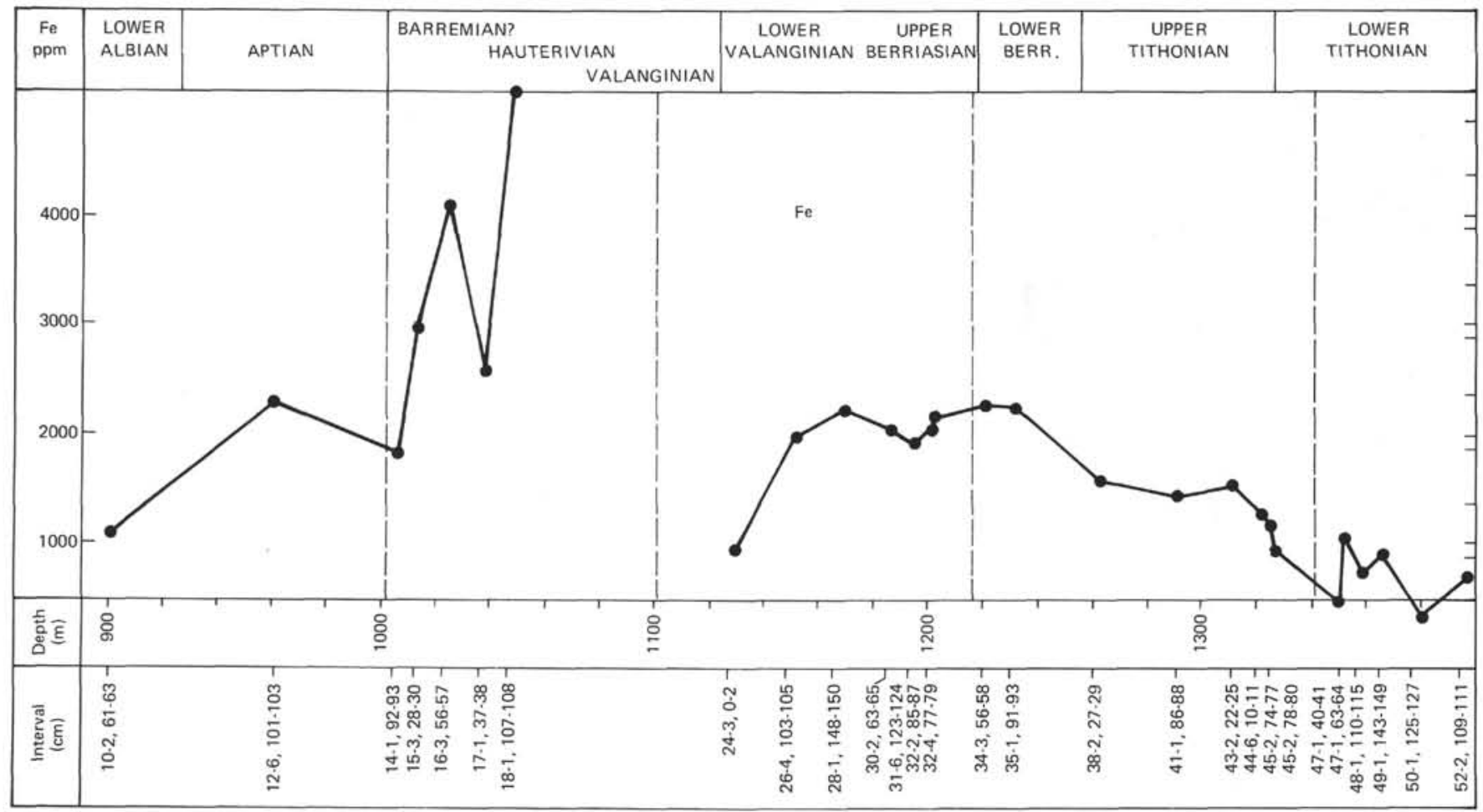

Figure 5. Distribution of iron contents in Hole 391C.

We can speculate that the Tertiary oscillations reflect the beginning of a connection between the Atlantic and Arctic oceans, but we cannot presently present conclusive evidence in support of that view. The range and average strontium concentrations at different stratigraphic levels are given in Figure 8.

\section{Manganese}

The manganese concentrations at Holes 390 and 390A are always lower than $500 \mathrm{ppm}$ (Figure 9). The amounts measured for Barremian samples are similar to those for corresponding samples in Hole 391C. The Albian samples, however, never have high manganese concentrations. Man- ganese concentrations decrease above the Tertiary/ Cretaceous boundary although the decrease is less distinct than that of strontium. The lower Eocene sediments are poor in manganese and the upper boundary of the middle Miocene is marked by a rapid increase in manganese. These variations are not related to volcanic activity but to oxidation-reduction mechanisms; thus three sequences must have been deposited under reducing conditions.

1) The lower Eocene (Samples 5-1, 70-72 to 7-4, 138$140 \mathrm{~cm}$ );

2) The lower Maestrichtian (Samples 390A-14-1, 12-14 $\mathrm{cm}$ to $14-5,5-7 \mathrm{~cm}$; Hole $390 \mathrm{~A}$ );

3) Part of the Barremian (Samples 390-8-4, 131-133 cm to $9-1,78-80 \mathrm{~cm}$ ). 
TABLE 3

Results of Trace Element Analyses, Hole 390A

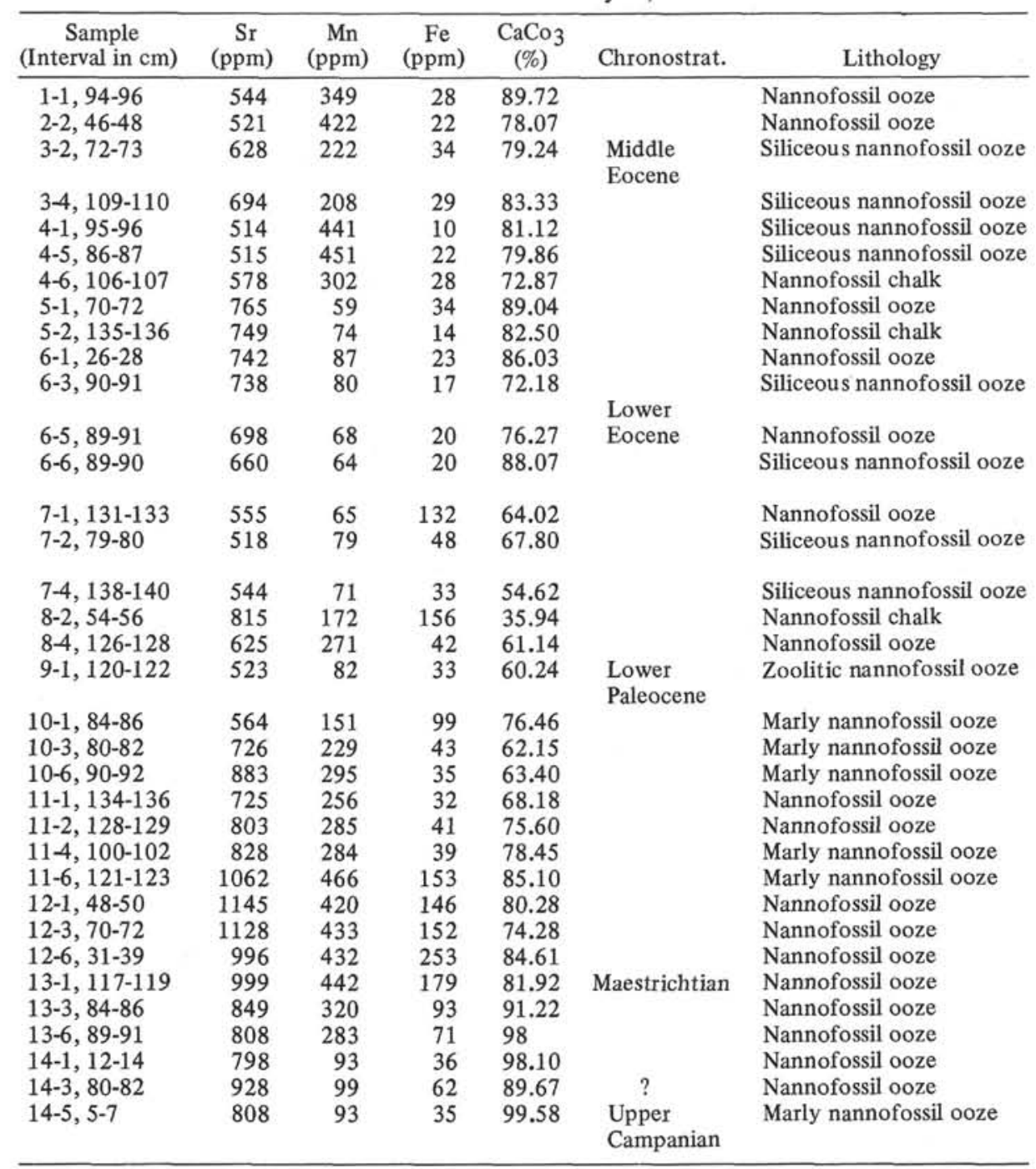

TABLE 4

Results of Trace Element Analyses, Hole 392A

\begin{tabular}{lrcrcll}
\hline $\begin{array}{c}\text { Sample } \\
\text { (Interval in cm) }\end{array}$ & $\begin{array}{c}\mathrm{Sr} \\
(\mathrm{ppm})\end{array}$ & $\begin{array}{c}\mathrm{Mn} \\
(\mathrm{ppm})\end{array}$ & $\begin{array}{c}\mathrm{Fe} \\
(\mathrm{ppm})\end{array}$ & $\begin{array}{c}\mathrm{CaCO}_{3} \\
(\%)\end{array}$ & \multicolumn{1}{c}{ Chronostrat. } & \multicolumn{1}{c}{ Lithology } \\
\hline $1-1,124-126$ & 715 & 39 & 23 & 90.39 & Upper Campanian & Foram-nannofossil ooze \\
$1-2,144-145$ & 956 & 83 & 46 & 89.39 & Upper Campanian & Foram-nannofossil ooze \\
$2-1,49-50$ & 1630 & 130 & 953 & 53.17 & Lower Albian & Marly-nannofossil ooze \\
$2-2,19-23$ & 308 & 175 & 377 & 72.20 & Lower Albian & Marly-nannofossil ooze \\
$3-1,102-104$ & 737 & 144 & 667 & 53.13 & Upper Aptian & Marly-nannofossil ooze \\
$3-2,105-106$ & 259 & 139 & 135 & 86.31 & Upper Aptian & Nannofossil ooze \\
$3-3,70-71$ & 232 & 89 & 57 & 69.51 & Upper Aptian & Nannofossil ooze \\
$4-1,125-126$ & 952 & 122 & 391 & 44.40 & Barremian & Lime mudstone \\
\hline
\end{tabular}

\section{Iron}

The iron-concentration curve for Holes 390 and 390A is very different for the Cretaceous and Tertiary sediments (Figure 10). The latter, notably the Eocene, is homogeneous and poor in iron $(\times 100 \mathrm{ppm})$, whereas the iron concentrations in Cretaceous sediments are generally higher and more variable. In contrast to strontium and manganese, iron concentrations are not noticeably different toward the top of the lower Eocene.

\section{HOLE 392A}

We do not have enough samples from this hole to adequately describe a general geochemical evolution, but the concentration curves of strontium, manganese, and iron seem to show the same trend as seen in sediments from Hole 390A (Figure 11). The rapid decrease of strontium concentrations down section through the Albian sediments is particularly evident. The values of the manganese concentrations are the same in Holes 390A and 392A. As in Hole 


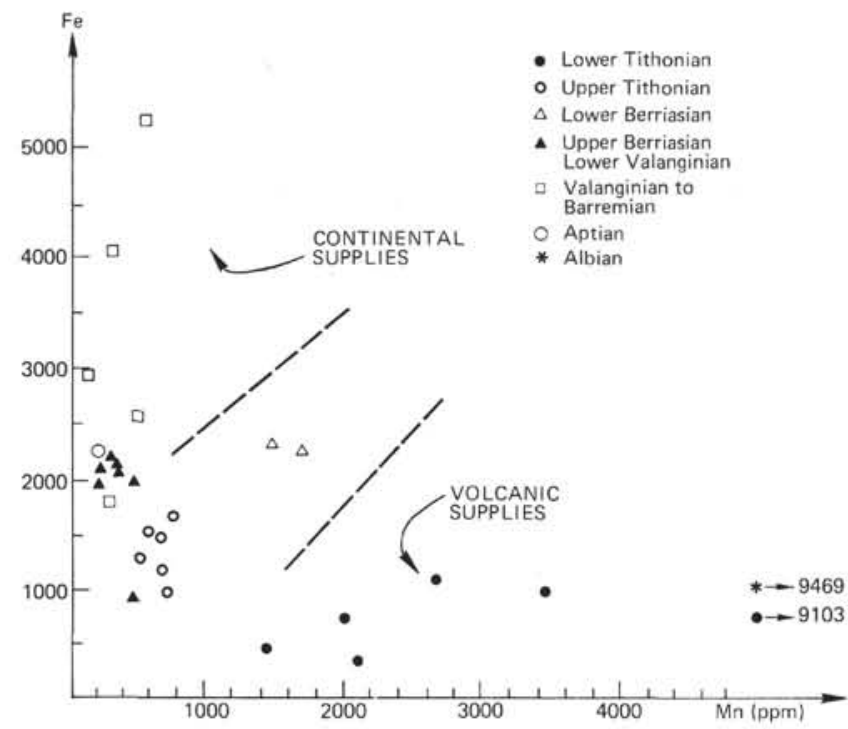

Figure 6. Relationship between manganese and iron concentrations in Hole 391C.
390 A the iron curve shows a great variability, but in Hole $392 \mathrm{~A}$ the iron concentrations are higher.

\section{ACKNOWLEDGMENTS}

This work was performed with the assistance of the Centre National d'Exploitation des Océans (France).

We are grateful to Mr. Michel Petzold for preparation of the figures and to Mrs. Chantal Odin for typing various drafts of the manuscript. We thank also Mr. Olivier Canaveso, and Mr. and Mrs. Kleyn for correction of the English text.

\section{REFERENCES}

Kinsmann, D.J.J., 1969. Interpretation of $\mathrm{Sr}^{2}+$ concentrations in carbonate minerals and rocks: J. Sediment. Petrol., 39, p. 486-508.

Michard, G., 1969. Contribution a l'étude du comportement du Manganes̀e dans sédimentation: Thes̀e, Univ. Paris.

1975. L'action de l'eau de mer sur les basaltes, source possible du manganèse. Etude thermodynamique préliminaire: C.R. Acad. Sci Paris, v. 280, ser. D, p. 1213-1215.

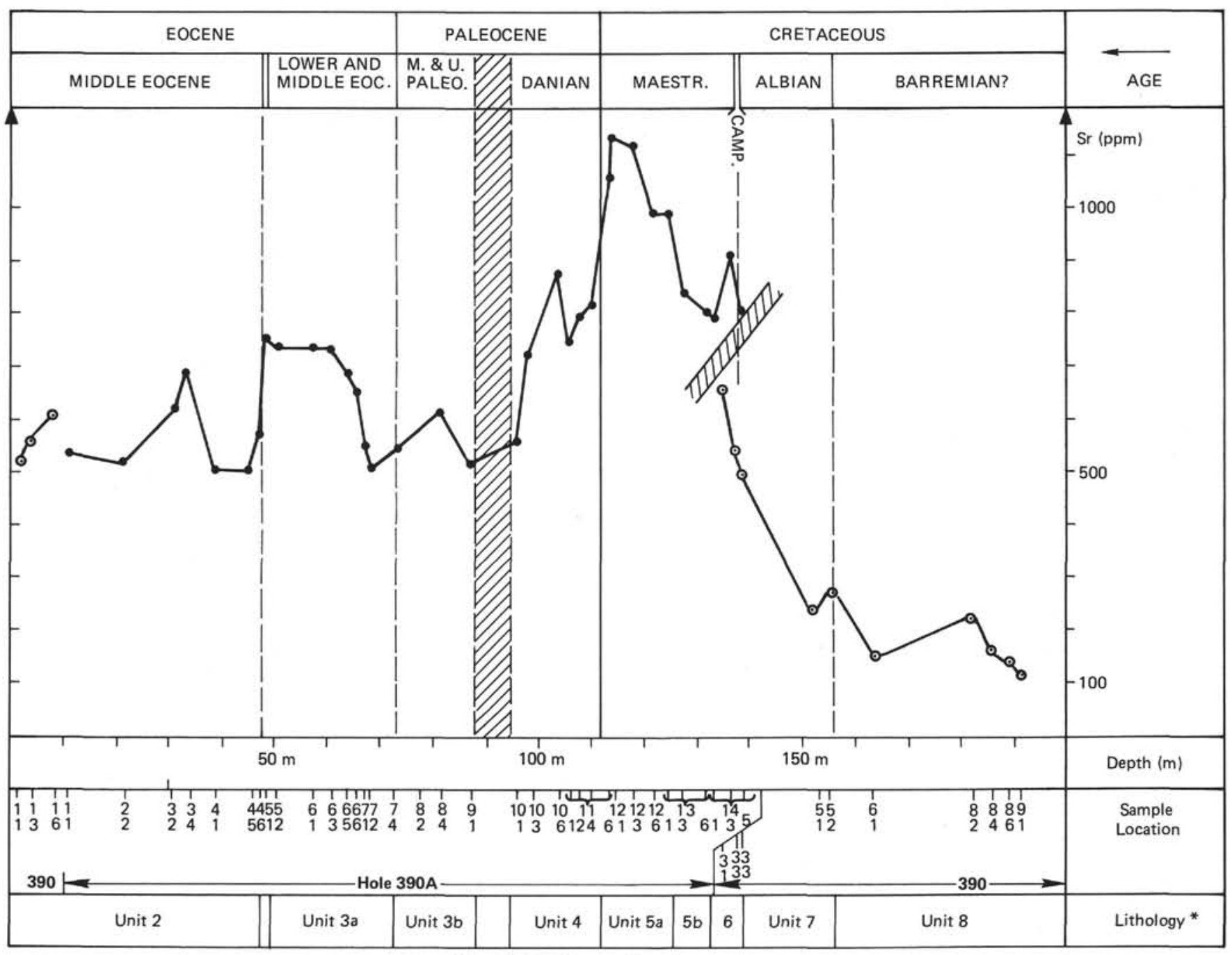

*See Site 390 Report, this volume.

Figure 7. Strontium concentrations in Holes 390, 390A. 


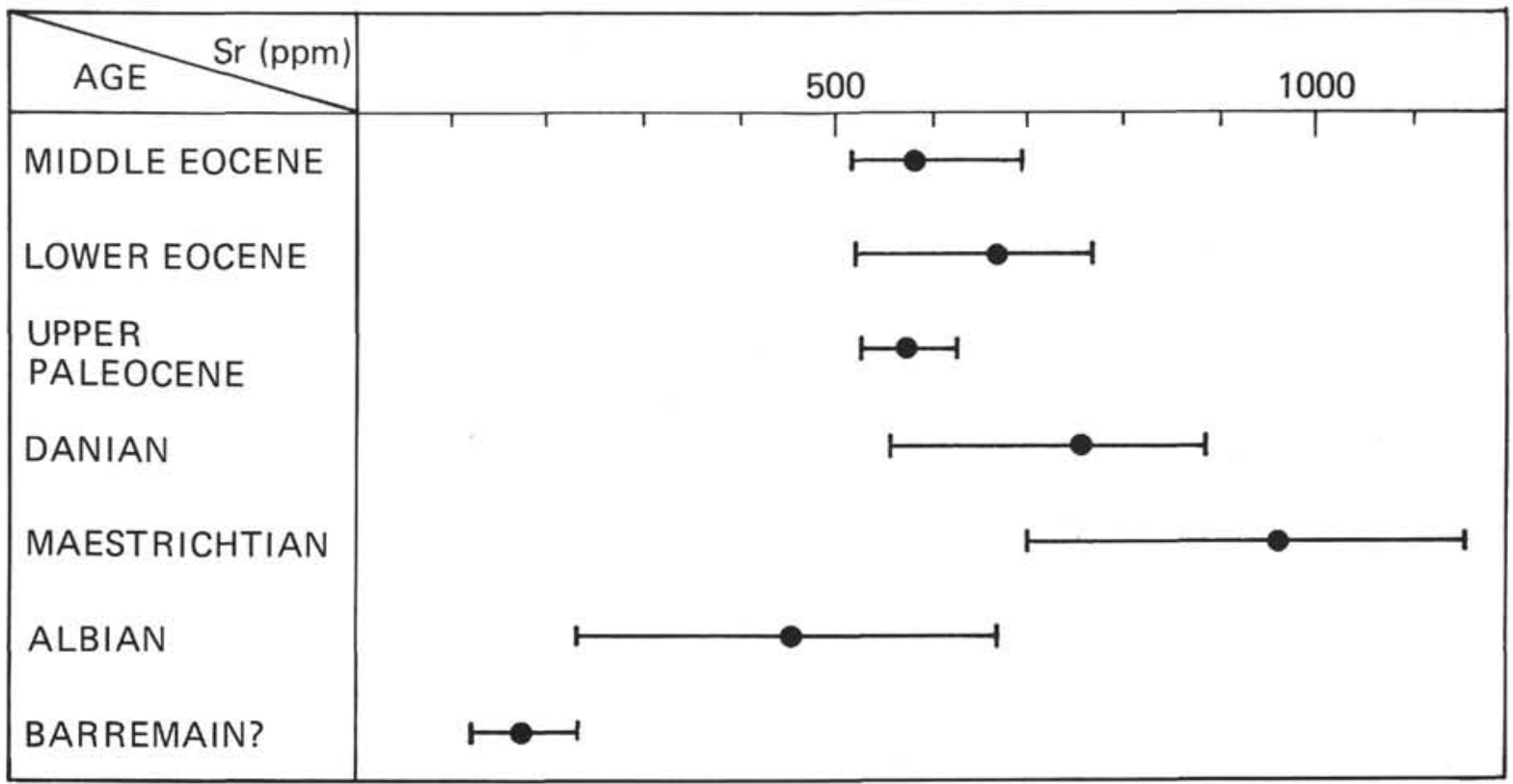

Figure 8. Range and average strontium concentrations in the different stratigraphic levels in Holes $390,390 \mathrm{~A}$.

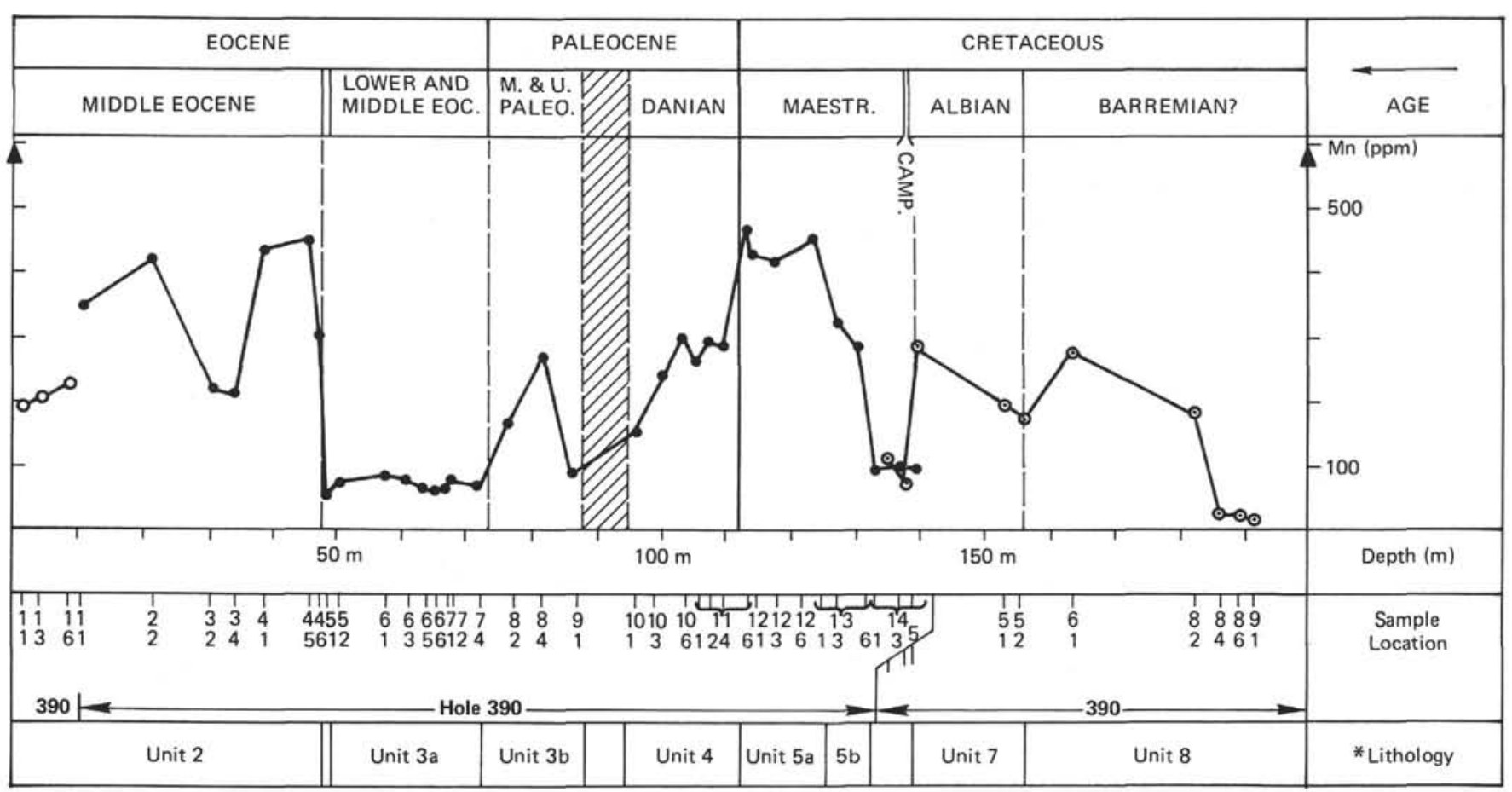

* See Site 390 Report, this volume.

Figure 9. Manganese concentrations in Holes 390, 390A.

Renard, M. and Blanc $\mathrm{Ph} .$, 1971. Mise au point d'un protocole ex perimental pour le dosage d'éléments en traces $(\mathrm{V}, \mathrm{Cr}, \mathrm{Mn}, \mathrm{Ni}$, Sr, Mo) par absorption atomique: C.R. Acad. Sci. Paris, clv. 272, p. 2285-2288.

1972. Influence des conditions de mise en solution (choix de l'acide, température et durée d'attaque) dans le dosage des elements en traces des roches carbonatées: C.R. Acad. Sci. Paris, v. 274, p. 632-635.
Renard, M., 1972. Interpretation des teneurs en strontium des carbonates du Lutétien supérieur a St Vaast-les-Mello (Oise). Mise en évidence de la valeur de cet élément comme indicateur des conditions de diagenèse et de sédimentation des carbonates: Bull. Assoc. Géol. Bassin Paris, v. 34, p. 19-29.

Sherman, D.J. and Shirmohammadi, N.H., 1969. Distribution of strontium in dolomites from the French Jura: Nature, v. 208, p. 1310-1311. 


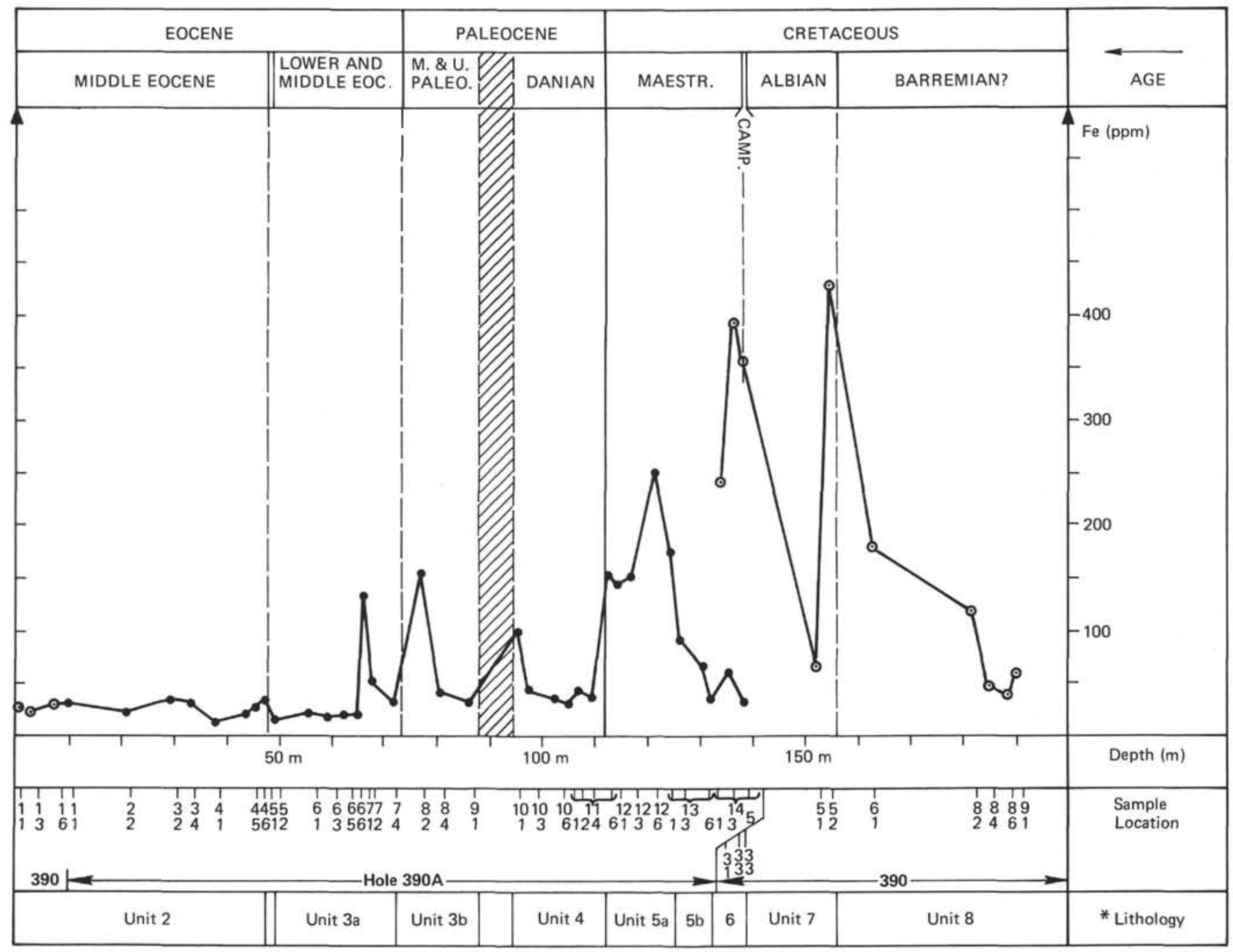

* See Site 390 Report, this volume.

Figure 10. Iron concentrations in Holes 390, 390A. 
M. RENARD, R. LËTOLLE, M. BOURBON, G. RICHEBOIS
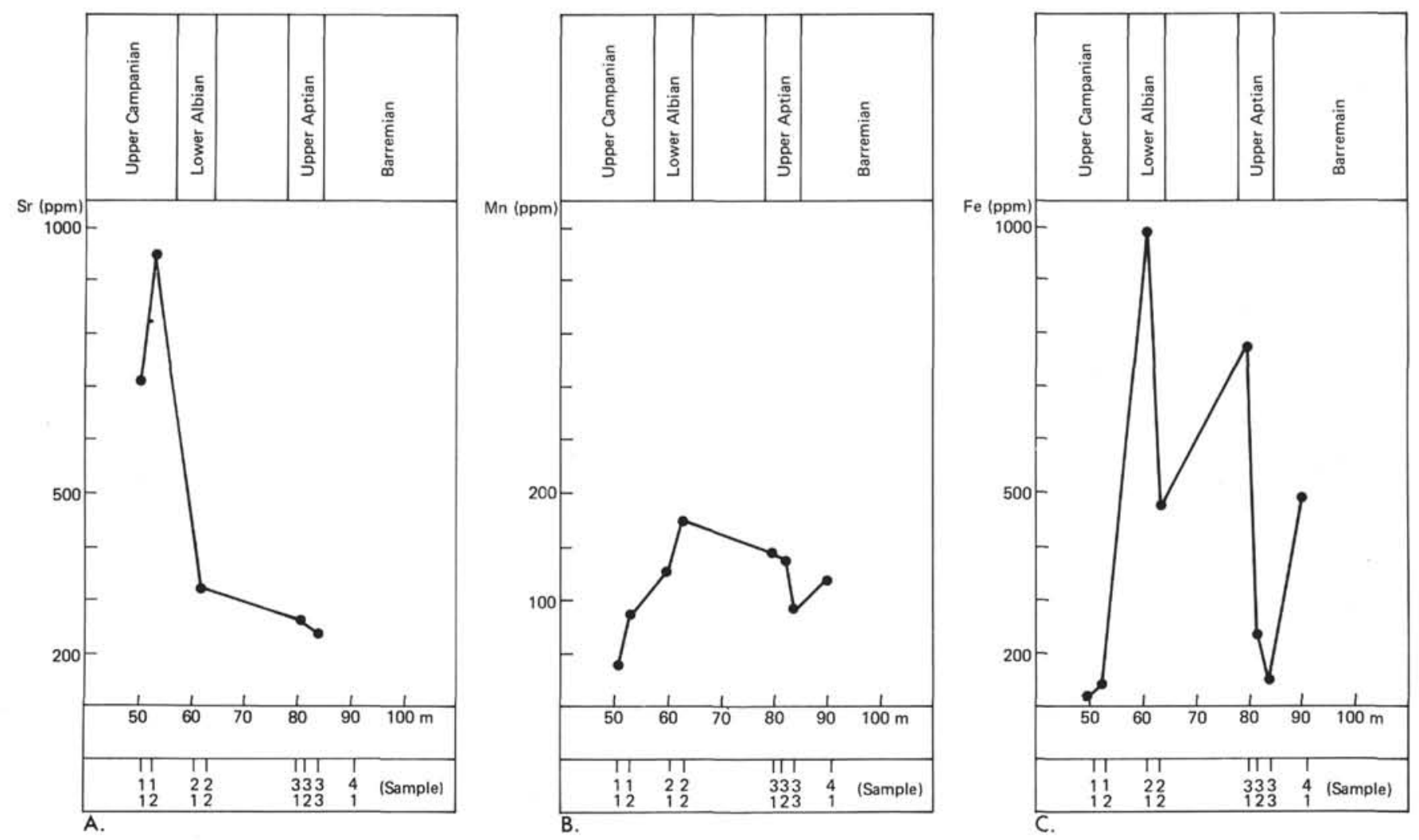

Figure 11. Concentrations of strontium (A), manganese (B), and iron (C) at Hole $392 \mathrm{~A}$. 